\title{
The Historian as Memory Practitioner
}

\begin{abstract}
Studying Africa without using African languages makes that continent a place most studied by non-Africans who have their own, often noble, agendas. If this sounds parochial or dramatic, imagine any Western European country's or American or Canadian history (and memory) researched and written by Africans in any African languages, such as isiXhosa, isiZulu, chiShona, Igbo, or even Kiswahili? What kind of history do you think those Africans, as historians and scholars of Europe, would produce? Whose interests would that scholarship serve first and foremost? Indeed, how many Europeans would read those African-originated histories and studies written in African languages? This chapter invites a conversation about African languages in the research and narration of African histories and cultures for African ontological and epistemological freedom, and global reconsideration.
\end{abstract}

Invocation:

Jan-Georg Deutsch: you lived well. You loved well, and are still deeply loved by those who remember your life and work. Look at what your life's work has brought forth, an extraordinary volume of work presented here, and elsewhere among those whose lives you touched.

To the living: Let your sorrow be tempered by the knowledge that you have another intimate ancestor in the winds. We lift your memory, Jan-Georg, to the company of all our personal ancestors, and yours, and to the Source of all that is. Rest in glory.

\section{Reckoning with the Long Cold Shadow of Feigned Racial Innocence}

In early April 2015, my beloved dog Chipo and I went for a walk in the northwest hills of Austin, Texas, where we lived at the time. Chipo was an intrepid Portuguese Water Dog in love with life. Every day of her life, she inspected the trails with her nose as though encountering them for the first time. She embodied what one might call the daily practice of engaged and embodied encounters. On that April morning, I followed Chipo as she elegantly and gracefully sniffed and jumped her way up a rock cliff; while I lumbered along, plotting each move 
based on how much rock or tree stump I could grab without sliding down or disturbing a snoozing snake. When I saw Chipo leap over a tree stump, I reached for it pulling myself up the rock, and as I did so, I felt something supple. Atop the rock, I turned around and was struck by the fact that the stump was both dead and alive. The original tree was gone, yet it was alive with roots deep in the ground still feeding dozens of new shoots that I could not see from the lower end of the rock. It is to that dead-but-alive tree in then drought-stricken central Texas, that I reach for a metaphor for the first two parts of this chapter-the stump as history and its shoots as memory.

The metaphor returned to my conscious mind in early 2017 as Chipo and me walked the woods of our new home in Switzerland, introducing ourselves to the land, its people, the mountains and forests and other beings that call those forests and the landscapes home. That stump and its lush new shoots returned because, I realised, though I had visited and stayed in Switzerland, and Western Europe, for short periods before (a year at most), this time I was staying longterm, and so had beginners' eyes. I was encountering Europe at home, not the colonial or postcolonial Europe of Africa, the continent of my birth, or of North America, my adopted continent. I was encountering a Europe alive to its display of (what it considers) its uniqueness, success, and superiority over all Others landing on its southern and eastern shores, dead or alive. The stump and its fresh signs of revival also came to mind because my very existence, my humanness as a Black person in these parts was, and is, representative of those too often drowning migrants - people who "do not belong" in Europe. My being an Other - and I capitalise the word on purpose here - was something I was going to have to get used to in this place where silent, stony stares, or some other form of passive-aggressive behaviour told (and tells) me in a thousand little humiliating ways - "You do not belong here." To be sure this was not my first experience of racialised encounters, as in the Southern Africa of my birth, conversations about the legacy of colonial and racial histories are still inflected by the unhealed traumas of European imperialism, apartheid, and the psychic introjection of internalised racial inferiority. All this was nurtured by anxious and brutal settler colonialism that, in turn, birthed deeply colonised nationalist leaders many of whom inflicted further harm on their own people once in power. $^{1}$

1 On this psychic introjection, see among others, Frantz Fanon, Black Skin, White Masks (New York: Grove Press Inc., 1967), Steve Bantu Biko, I Write What I Like: Selected Writings (Chicago: University of Chicago Press, 2002); Mamphela Ramphele, Across Boundaries: The Journey of a South African Woman Leader (New York: Feminist Press, 1999). 
In the North America of my choice, ${ }^{2}$ conversations about the legacy of colonial and racial histories are inflected by many strands, two of which are important in this discussion. First, the continued settler colonialism and subjugation of the First Peoples who, though present in cities and other spaces, are often portrayed as only alive in reservations. ${ }^{3}$ In the United States, for example, the whitewashed history of the country glorifies colonial history through tropes of intrepid and resilient European pioneers who tamed a savage land and its savage peoples. ${ }^{4}$ This frontier gospel is telegraphed to (naïve?) new immigrants as the American Dream with the cumulative effect of suggesting that Indigenous Peoples prefer to live in reservations, as though they chose it for themselves in the first place. ${ }^{5}$ The historian who practices a history focused on the conqueror, even when telling stories of the vanquished, unwittingly practices the memory for the powerful. Second, the cruel history and long cold shadow of enslavement means that African Americans, from 1619 to the present, have had to fight for every inch of freedom that is their birth right, freedom that enshrines their full humanity. ${ }^{6}$ All to say, in both Southern Africa and North America, the colonial past and its racialised cruelties are present in vivid ways that have defined continental and diasporic African experiences. A similar experience marks most Indigenous (American) experiences as their histories and cultures have been under assault, including incorporation into mainstream culture as part of the settler-American experience that glorifies the settler and the immigrant at the expense of the indigenous peoples.

By contrast, in Switzerland and in in Western Europe, I encountered a practice of memory steeped in amnesia, an amnesia that postured a Europe innocent

2 By North America, I particularly mean Canada and the United States, my adopted countries. This, however, does not exclude the third North American country, Mexico, or Central and South America from racist colonial histories with Spain, and Portugal.

3 See among others, Vine Deloria, Jr., Custer Died for Your Sins: An Indian Manifesto (Norman: University of Oklahoma Press, 1988); Roxanne Dunbar-Ortiz, An Indigenous Peoples' History of the United States (Boston: Beacon Press, 2014).

4 Paula Gunn Allen, "Introduction," in Spider Woman's Granddaughters: Traditional and Contemporary Writing by Native American Women, ed. Paula Gunn Allen (New York: Fawcett Books, 1989), 1-25.

5 Recent critical engagements with this historical erasure includes, among others: Joy Harjo, An American Sunrise: Poems (New York: W.W. Norton \& Company, 2019); Layli Long Soldier, Whereas: Poems (Minneapolis: Graywolf Press, 2017); Tommy Orange, There There (New York: Vintage 2019).

6 See among others, James Baldwin, James Baldwin: Collected Essays, Collected by Toni Morrison (New York: The Library of America, 1998). 
of the racial discord that has marked our world for the past five hundred years. ${ }^{7}$ For example, I cannot tell you how often some people who style themselves simple Swiss folk habitually invoke their simple-ness (which is not the same as simplicity) with certitude, while clutching at some old irrational ideas about black and brown bodies, like: black people do not burn in the sun because they have dark skin. Or the desire to have a black friend and at the first shared laughter at something funny, there's an assumed intimacy where someone (white) immediately reaches to touch a black person's hair as though one's personhood were a petting zoo. Even in a zoo, touching cannot be cavalierly permitted as it assumes that we, humans, are entitled to other creatures' lives and bodily integrity. These anecdotes may seem trivial compared to the behemoth of white supremacy, but that is my point: white supremacy's foundation is girded and anchored by such wilful (and supposedly simple) ignorance among ordinary European people who, though literate and highly skilled at their trades, are often unwilling to educate themselves in their claim to white inheritance through "first world," now Global North, status. James Baldwin articulated the problem with white innocence and simple-ness in his essay "Stranger in the Village" about his experience in a Swiss village, an essay whose thunder's rumbling I will not steal by summarising it. ${ }^{8}$ Toni Morrison deepened Baldwin's articulation with her own revolutionary take on the making of European whiteness in the United States through its literature. ${ }^{9}$ These intellectuals' works urge the historian of continental and diasporic Africans to confront the feigned innocence of continental and settler Europeans in the making and telling of racialised histories, at home and abroad. It not only liberates those oppressed by history, but it also liberates those who inherited such an oppressive history.

The urgency of the "The Historian as Memory Practitioner" that is the title of this chapter, then, crystallised in my mind one day while I was going about my normal errands of everyday life in Switzerland without experiencing those overt or subtly racialised dramas. As I drove home without an incident to process or drown out with some soothing music, it occurred to me that I needed to figure out how to change my response in this reserved (or repressed?) society, from one of silent retreat and internalising the pain and humiliations to one of engaged citizenship to those who claim to be "innocent" white people from an Alpine

7 See, for example, essays in Patricia Purtschert and Harald Fischer-Tiné, eds., Colonial Switzerland: Rethinking Colonialism from the Margins (London: Palgrave Macmillan, 2015).

8 Baldwin, James Baldwin: Collected Essays, 117-129.

9 Toni Morrison, Playing in the Dark: Whiteness and the Literary Imagination (New York: Vintage Books, 1992). 
country, much like Heidi and Alm-Uncle, her grandfather. ${ }^{10}$ For my part, I decided that instead of stoically looking on, striking a resistant pose and rejecting the typecasting as just "eine schwarze/dunkle Frau" (a black or dark woman), I would turn to history for some answers as it occurred to me that in most encounters many people do not know much history, their own or others'. This is compounded when they see in me, or another person of African descent, a foreigner who does not belong in "their white country," instead of just another human being searching for life's meaning. Remembering that I was also a trained historian meant that I chose not to play the politics of respectability, choosing instead, to find a way to assert my historical knowledge so people can make sense of the dissonance that our racially charged encounters dredge up from our psyches. Afterall, this is the same country (Switzerland) from whence emerged that other godfather of modern psychoanalysis, Carl Gustav Jung, whose views on African minds exercise Jungian scholars and practitioners. ${ }^{11}$ And as a student and historian of European encounters with "Others" in their parts of the world, then, I needed to be a scholar who challenges these amnesiac responses to Europe's inheritance by holding up the mirror of history, a racialised history, that contemporary memory would rather forget; a mirror that shows that Europe is neither innocent nor untouched by the making of racialised others in Africa and elsewhere. After all, we are all living in a global capitalist system originally designed in Europe with not much care for the Earth or non-Europeans. This is a hard conversation we all need to have on (and not under) the table, so we subjectively and objectively reckon with our own complicity in maintaining the white supremacist status quo in academia. I see myself in that same mirror of complicity as I am not just holding it up for others with an accusatory finger.

This recognition of my body and my place in everyday life, now that I live in Europe, has had the same awakening effect as that April day when I followed Chipo up the rock face and my hands touched the dead tree stump and its supple shoots. The stump of history seems embodied in black and brown bodies, reminding Europe of its past self, even as contemporary Europe clutches at the new supple shoots of its precious economic prosperity against what it sees as hordes landing on its shores, eager to devour that prosperity. My practice of the discipline of History, more than ever, has to consciously include my skin col-

10 Names borrowed from the children's novel, Heidi, by Johanna Spyri.

11 Here I am focused on Switzerland, hence my mention of Jung only. Farhad Dalal initiated an examination of Jung's body of work with a focus on race and published a paradigm shifting article, “Jung: A Racist” British Journal of Psychotherapy, no. 4 (1988): 263-279. Responses to Dalal's article include, the British Psychotherapy Foundation, “Jung and Racism," accessed 25 February 2021, https://www.britishpsychotherapyfoundation.org.uk/insights/blog/jung-and-racism. 
our as the perfect conduit for not only bearing witness to the lives of striving fellow human beings crossing the Mediterranean Sea, or some other physical and psychic geography around the world, but holding space for the awkward conversations that need to be had in countries that imagine racism does not exist in a country like Heidi's alpine country. In this chapter, then, I invite everyone into a spirited conversation about the importance of rigorous scholarship that remembers or commemorates the imagined place we call "the West" and its place in African history and memory. ${ }^{12}$ Take, for example, the forgetting of European mass emigration in the nineteenth century, right into the middle of the twentieth, that needs reconsideration. It was a time when millions of ordinary (and often poor) Europeans eagerly boarded both legal and illegal ships destined for distant shores. This is the subject of my second book that I hope will contribute something important in our study of European imperial and colonial histories in Africa. I say this because in African History, the overwhelming narrative of European migration and immigration to parts of the continent are mainly studied through the lens of the colonial project and its civilising mission. What if we asked new questions, because those European emigrants and migrants were not unlike many of the brave young people crossing or drowning in the Mediterranean Sea today. A century or two ago it was mostly young Europeans who crossed the treacherous seas in large numbers to become Americans, Canadians, Australians, New Zealanders, South Africans, or Rhodesians. Then as now, they were in search of a better life for themselves and their families. The critical difference, of course, is that one set of migrants and immigrants had Western European imperialism and whiteness as foundation, anchor, and protection; while the other set, has colonialism and their black or brownness as source of rejection and or inhumane treatment.

\section{Language as the Practice of History}

I began this chapter with an anecdote related to a canine and a sprouting tree stump in a rocky forest because it also stirred my thinking about how many of us historians and scholars of Africa have denatured Africans in our bid to show (who?) that Africans are not the gyrating savages of the wild bush in European colonial history. At some level, it seems to me, we continue the ancestor

12 Historian Dipesh Chakrabarty's argument about the importance of other worlds and their ontologies in modern thought informs my own thinking here. See Dipesh Chakrabarty, Provincializing Europe: Political Thought and Historical Difference (Princeton: Princeton University Press, 2007). 
worship of Georg Hegel, a ritual revived by Hugh Trevor-Roper in the 1960s. ${ }^{13}$ To that end, I will not quote these men as the continued repetition of their spiteful words and wilful ignorance continue to feed racist rhetoric toward Africans and people of African descent everywhere. ${ }^{14}$ It seems to me we continue this practice of ancestor-worshipping Hegel and his ilk by our willingness to wear the blindfold of whitewashed history, excluding African languages from our practice of historiography, save for those doing historical linguistics. ${ }^{15}$ We seem to choose to practice African history primarily in Western languages, and more so in that special dialect called academese in which only a few are fluent and literate. Hegel's views may seem dead at this point because several generations of Africans and Africanist scholars have engaged with those views, yet it would seem, Hegel and his disciples still have us mesmerised unable to break their hypnotic appeal of quoting them as a sign of learning. Hegel's views are the dead treestump of history whose deep roots are nurturing new shoots that hold both barbed and warped views about Africa. They also manifest as the ever-expanding benevolent intentions that send aid to Africa, an Africa that still functions as the world's posterchild for charity. As I understand it, Jan-Georg Deutsch, was on a new scholarly path, studying commemoration with a focus on slave museums around Africa. ${ }^{16}$ What this suggests to me is that any serious scholar, at some point in their life, must reckon with the deeper truths of the histories they study, including the uncomfortable truths that show us our own complicity in narrating Africa for audiences that do not include the majority of Africans. For us all, and especially the next generation of scholars, this is a call to recognise African agency so the majority of Africans can see themselves - their individual selves and their collective histories - in the works of historians and scholars of Africa, and global studies, too. ${ }^{17}$ I think we all can agree that the majority of

13 See, for example, Finn Fuglestad, "The Trevor-Roper Trap or the Imperialism of History: An Essay," History in Africa 19 (1992): 309-326.

14 Georg W.F. Hegel, The Philosophy of History, trans. J. Sibree (Kitchener, ON: Batoche Books, 2001), $109-112$.

15 My earlier critique of this ancestor worship is found in: Ruramisai Charumbira, "Ancestor Worship: Just Who is Worshipping Whom?: Theoretical and Methodological Reflections on Power and Knowledge about Africa." (M.A. Thesis, University of Toronto, 2001), accessed 25 February 2021, https://tspace.library.utoronto.ca/bitstream/1807/15836/1/MQ63231.pdf.

16 Personal communication from the conference organisers, October 2017, and his obituary: “Jan-Georg Deutsch," Faculty of History, University of Oxford, 23 December 2016, accessed 18 December 2020 https://www.history.ox.ac.uk/article/jan-georg-deutsch.

17 See another tribute by Festo Mkenda here: Festo Mkenda, "A Tribute to Jan-Georg Deutsch (1956-2016," Africa Oxford Initiative, University of Oxford, 22 December 2017, accessed 18 December 2020, http://www.afox.ox.ac.uk/news/a-tribute-to-jan-georg-deutsch/. 
Africans have a right to read many of those histories in the languages of their intimacies, the languages in which they make love and sing to their children; languages some choose to mash-up with former colonial ones to form new expressions. ${ }^{18}$ The majority of Africans deserve histories that open not just their own eyes, but those of Others, too, so everyone can see Africa again, for the first time. This is the practice of daily engaged encounters that I learned from my dog, Chipo; that tenacious and focused scholarship that is inviting like a book of fiction and yet deeply generous like a well-researched monograph, affording readers a revelation of some kind.

This brings me back to the important issue of nature in African histories and African Studies practiced in African languages. The inimitable Ngũgĩ wa Thiong'o is probably one of the most focused and tenacious advocates of African languages in literature and scholarly endeavours. In his many works, especially in Something Torn and New: An African Renaissance, he argues for an Africa revitalised and powered by African languages. ${ }^{19}$ African languages are the memory bank not fully utilised in the study of the bulk of African histories. African languages (not just a word here and there) are primary sources with potential to not only power the arts as they already do, but also the growth of the natural and social sciences, new technologies, and innovation in imagining climate renewal in this century and beyond. To those who raise an eyebrow to that assertion about African languages' potency, Ngũgĩ, in the aforementioned text, emphasises that it is worth remembering that not too long ago, the powerful contemporary languages of Western Europe were once considered vernaculars, "far inferior," and not sophisticated enough to articulate science, literature, philosophy, technological advancement, and all scholarly learning which was deemed to derive from the Greek and Latin languages - colonial languages to those non-Greek and non-Latin Europeans. Yet, in the last four centuries or so, some of those same European vernaculars - especially English, French, and Portuguese - have had a grip on Africa as the languages of the humanities, sciences, mathematics, engineering and technology in much of Africa's education systems. The argument is that there is no math or science in African cultures and traditions, and therefore no language for those fields of study, which tells me that we, historians, have been far too focused on the racists rather than showing and tell-

18 John Mugane's introductory piece, and articles in this issue are all worth reading on what I am discussing here; see: John Mugane, "Contemporary Conversations: Is English an African Language?” Journal of African Cultural Studies 30, no. 2 (2017): 121-123.

19 It is important to reiterate that I am not discussing some primordial essentialism when discussing indigenous languages or ways of being in Africa. See, Ngũgĩ wa Thiong’o, Something Torn and New: An African Renaissance (New York: Basic Civitas Books, 2009). 
ing African narratives that include African languages. Ngũgĩ's critical argument, then, is that as long as Africans (and Africanists) do not write (some of) their works in African languages, with the majority of continental Africans and diasporic Africans in mind, Africa cannot bequeath to its own peoples, and to the world, a renaissance that all deserve.

By not using African languages to write and imagine new African histories and African Studies, Africa remains a place most studied by non-Africans who have their own, often noble, agendas. If this sounds parochial or dramatic, imagine any Western European country's or American or Canadian history (and memory) researched and written by Africans in any African languages, such as isiXhosa, isiZulu, chiShona, Igbo, or even Kiswahili? What kind of history do you think those Africans as historians and scholars of Europe would produce? Whose interests would it serve first and foremost? Indeed, how many Europeans would read those African originated histories written in African languages? This, of course, is not to say no one else but Africans can or should write about Africa; nor is it to choke the creativity and self-expression of those non-Africans passionate about the continent's deep and recent past in any language. If it is any comfort, some of my most cherished teachers of Africa were non-Africans, and some were fluent in the languages of the peoples they studied. What I am insisting on here is that within a language lies the memory bank of a people's culture, their ontological and epistemological freedoms where they can reimagine themselves and innovate anew. Thus, being a memory practitioner of African scholarship means holding up the mirror to oneself before holding it out to others. By holding the mirror up to oneself and one's practices, one examines not just the documents in the archives and libraries, but the full meaning and effect of one's work in the world.

To illustrate my foregoing point, I will also use a non-African example of the philosopher-historian Paul Ricoeur's magisterial work Memory, History, Forgetting to illustrate my point about the importance of language in the histories we study and practice, African or otherwise. ${ }^{20}$ I designed and taught a graduate course for many years entitled "History and Memory" in which I assigned Ricoeur's book as a core reading requirement that most students found challenging at first. I taught it in sections throughout the semester, and as we slowly read through the text and went over passages together carefully, it won students' applause because it illustrated an important point: valuing the languages of those whose history is under study yields a much richer history. Ricoeur's text takes a

20 Paul Ricoeur, Memory, History, Forgetting, trans. Kathleen Blamey and David Pellauer (Chicago, Ill: University of Chicago Press, 2010). 
long view of history and memory in the Western philosophic and historical canon, starting with the ancient Greeks through the Romans to modern times. In each chapter he reminds us that he is not writing an intellectual history of all the world's scholarly thought on history, memory, and forgetting, but rather a very European-centred history with assumed resonances in other parts of the world. For Ricoeur, the written text is the central reservoir of deep historical knowledge, and the ability to read and interpret those texts gives his book its Europeanness that invites its readers to the original texts and their interpretations over the ages. My point here is that Ricoeur did what students of African history and African Studies do not do much of these days, immersion in the first languages of the people studied. To my mind, the importance of African languages is that they "re-member" African lives in relation to the past and present. ${ }^{21}$ This is much the same that scholars of British, Italian, German, or French histories do, using those languages to re-member those histories, illuminating the past for the insider and outsider, including the contested historical roots of some of those languages and cultures. On the other hand, it is also true that we all write for different publics and audiences, but my point here is that it is striking that there is far more written about Africa and Africans not aimed at the majority of Africans but global (read western) eyes. This raises the question: who needs written history, the powerful or ordinary folk?

Back to Africa and nature, the late political historian, Ali Mazrui, famously said: "Geography is the mother of history."22 By which he meant that "the most potent indigenous force in Africa's experience is Africa's environment, the combined elements of geophysical features, location and climate."23 While geography is not the same as nature, I use it here in the idiomatic sense to reiterate the importance of African languages to the study of African people's lives and the importance of knowing not just what names Africans gave to their physical geographies across the continent, but the context of those names and the historical and contemporary meanings embedded in those names. I analysed this issue in my first book, Imagining a Nation: History and Memory in Making Zimbabwe, a book that made some of the mistakes I critique here, hence I am not

21 For an original inspiration, see Ngũgĩ wa Thiong’o, Re-membering Africa (Nairobi: East African Educational Publishers, 2009.)

22 Ali Mazrui, The Africans: A Triple Heritage (Boston: Little, Brown and Company, 1986), 41. This book is a companion guide to his nine-part television series of the same name, accessed 18 December 2020, https://www.bbc.co.uk/programmes/p00gq1wn/episodes/player. See also his 1979 Reith Lectures: The African Condition.

23 Ibid. 
exempt. ${ }^{24}$ Be that as it may, I refer back to geography and nature to also ask: What use is nature and natural history to the historian, especially the historian of Africa still burdened with proving Hegel wrong? What use is nature when Africa's natural geography and its flora and fauna was (and is) what many people, including young people in the West today, think of when Africa comes to mind? What use is nature when Africa is "rising," yet it is still its natural resources that grease the wheels of international trade at Africa's expense? What use is nature even as Africa is putting the past behind, thanks to new technologies, especially information technology, that allows self-representation that does not need to rely on much else besides the self?

Guild historians, ${ }^{25}$ like most historians, spend hours and years in "the field," in the archives and in libraries, looking for, and gathering, materials that show a different Africa than the one Immanuel Kant or Georg Hegel declared. This includes the contemporary Africa of the "bleeding heart" television commercials and infomercials. These media representations generally appeal to the Westerners' sense of guilt over their material comforts in contrast to the poor people on the television screen cast as disempowered and demoralised, not just by a material reality that does not include running water, electricity, or even hope, but by their Africanness - or Third Worldness. Westerners are made to feel that their financial contributions will restore hope if only they could send a few euros or dollars or pounds to lift the poor out of their material poverty. The overarching narratives of these commercials and infomercials are that those poor people must battle with nature's elements like the West did during the long nineteenth-century. Now, there's nothing wrong with "lifting people out of poverty" to be sure, but if we remember that this lifting has been going on for generations in Africa's relationships with the West, then I would argue Hegel's assertions, though dead like that tree-stump are is still alive, nourishing new shoots from the same old craggy tree.

I would argue that in our telling African histories aimed at most Africans, we not only need to listen to Africans' narrative, but heed the late Toni Morrison's cautionary wisdom when she said: "No one can blame the conqueror for writing history the way he sees it, [...]. [H]istory supports and complements a very grave

24 Ruramisai Charumbira, Imagining a Nation: History and Memory in Making Zimbabwe (Charlottesville: University of Virginia Press, 2015), 101-103, more broadly, read through 77-137.

25 Here I specifically use guild to highlight the political power and influence academic historians have over the study of history in schools and universities - much more than (other professional) historians outside academia. 
and almost pristine ignorance." 26 The real problem, Morrison continues, is that the telling of the African and Africanist history has been too focused on trying to prove Africans' humanity, instead of showing African lives in all their complexity for, first and foremost, the Africans themselves; because something that is true and authentic will resonate beyond its particular community. "The function of racism is distraction" Morrison reminds us, "it keeps you explaining over and over again, your reason for being. Somebody says you have no language and so you spend 20 [sic] years proving that you do. Somebody says you don't have [...]."27 All of us, then, are challenged to not prioritise our becoming mere elite scholars; rather, maybe we ought to prioritise writing narratives that ordinary people can read and or take into their lives as a way of knowing and re-knowing themselves as conscious beings. To my mind, histories that illumine different avenues toward self-knowledge and actualisation are the holy grail of liberatory scholarship. It is a scholarship that seeks to break with the academic past that prioritises the elites of society and their epistemological ways in the narration of history, even when telling of ordinary people's histories. ${ }^{28}$

\section{Language as the Practice of Memory}

In this last section, I will conclude with three examples (not all from Africa or about Africans) that show the importance of embedding not only nature in African histories, but also getting history to be of service to the dead and the especially the living. Here, I will use the metaphor of water in a river to highlight the importance of innovation, creativity, and fluidity in the practice of the historian's craft in service of the subject. By insisting on returning nature to human history in Africa, I do not mean it as merely a part of "environmental history" or "environmental humanities," but as part of the human stories that Africans told and tell themselves about themselves and their geographies; stories they pass(ed) on

26 Portland State University; Morrison, Toni; St. John, Primus; Callahan, John; Callahan, Judy; and Baker, Lloyd, "Black Studies Center Public Dialogue. Pt. 2" (1975). Special Collections: Oregon Public Speakers, 90, accessed 18 December 2020, https://pdxscholar.library.pdx.edu/or speakers/90; Please note that though the above is the recommended citation from the original audio source, I used a transcript of Toni Morrison's talk done by Keisha E. McKenzie. Morrison's talk was entitled, “A Humanist View,” accessed 18 December 2020, https://www.mackenzian. com/wp-content/uploads/2014/07/Transcript_PortlandState_TMorrison.pdf.

27 Ibid.

28 Here, Walter Benjamin's essay "The Author as Producer” is worth reading for its insistence on writing with the regular person in mind - though some might argue that he did not make his own writing accessible. 
to their descendants, stories that could be lost in our bid to prove Hegel and his intellectual descendants wrong for the past two hundred or so years. The three women scholars whose lives and work I briefly consider in this section are scholars who rode and ride the currents of the rivers of time, place, and space to bring us to another understanding of what radical scholarship means. Radical here is not so much flame throwing as it is insistence that those who inherited the cruelties of recent history have a right to right the wrongs of history through the writing of memories they carry in their bodies and their communities. The common denominator among these three women is that they all experienced colonialism in some form in Africa (Kenya), east Pacific (New Zealand), and North America (USA.).

I consider these women scholars my mentors, too, for through their work, they continue the work my first mentor, my late mother, taught me to re-member the past and the future through reverence for all of life in the present; from the dust under my feet to the dust of stars in the Milky Way visible in the night sky at her homestead in Gutu. These three women scholars model the courage to make the return journey back to their intuitional intellectual roots without negating their academic disciplines, even as some were first wounded by their disciplines. They are not professional historians by training, but they each found individual ways to return to indigenous ways of knowing, which, for some, includes indigenous languages. The new scholarship each created, gave, and gives back to themselves, and to the communities from which they emerged, which include communities of the mind from whence they learned their scholarly and scientific skills. And by indigenous, I do not mean some esoteric and unchanging ways of knowing and being, I mean the return to that primordial spark within each of us, our beingness, no matter into what culture we were born. In other words, I am of the view that all humans are indigenous to this planet and this solar system, and some people, though scarred by the last five hundred years of racist history, still retain that deep love and kinship with the fullness of life on this our planet. Here, then, are the three women who model the historian as memory practitioner, expanding their own disciplines and fields of study through engaged and embodied transdisciplinary scholarship of history and memory. 


\section{Wangari Maathai of Kenya}

The late Maathai was educated in Kenya (her country of birth), and in the United States and Germany. ${ }^{29}$ She majored in biology, and it was that training she leaned on as she awakened to the importance of neglected indigenous knowledge systems of ecological diversity for solving economic development problems in the present. The importance of that indigenous knowledge was symbolised by the death and disappearance of a huge sycamore fig tree that once defined her youth growing up in Kenya. That fig tree, she learned, was in reciprocal relationship with the life forms it supported and was supported by, indirectly inspiring her scholastic trajectory as she spent hours, as a young girl, trying to catch frog eggs strung out like beads along the running water brook. ${ }^{30}$ It was not so much nostalgia for that particular tree for Maathai, but the realisation that all other life forms - the shrubs, birds, and the stream - had disappeared along with the fig tree, and the people were now poor waiting on, and hoping for, some international aid. She remembered that when she was a young girl, she was sent out to fetch firewood, she brought back wood from the sycamore fig tree near her home. Maathai's mother then taught her not to collect any firewood from the fig tree because, she said, it was "the Tree of God," requiring respect and care. What Maathai's mother and her community were teaching young Wangari was that the fig tree was both a foundational and dependent creature in an ecosystem sustained by a stream of fresh spring water that bubbled up from deep in the earth. ${ }^{31}$ Maathai's and her community's practice of animism, though not named as such, was what sustained a community that had not known what dependency on international aid meant. They passed the stories to their children, including young Wangari.

She went on to study biology and veterinary medicine at home and abroad, earning her doctorate; becoming an accidental environmental and political activist because gender discrimination and an untenable marriage shut her out of

29 Wangari Maathai, Unbowed: A Memoir (New York: Alfred A. Knopf, 2006).

30 Wangari Maathai, Replenishing the Earth: Spiritual Values for Healing Ourselves and the World (New York: Doubleday, 2010), Chs. 1-2; Wangari Maathai, Nobel Lecture, NobelPrize.org, accessed 18 December 2020, https://www.nobelprize.org/prizes/peace/2004/maathai/26050wangari-maathai-nobel-lecture-2004/.

31 For ecological discussion on what some call "keystone species," see, for example, Robert W. Paine, "Food Web Complexity and Species Diversity," American Naturalist 100, no. 910 (1966): 65-75; Kevin D. Lafferty and Thomas H. Suchanek, "Revisiting Paine’s 1966 Sea Star Removal Experiment, the Most-Cited Empirical Article in the American Naturalist" American Naturalist 188, no. 4 (2016): 365-378. 
academia. Together with the women and men she worked with, she founded the Green Belt Movement in 1977. That movement was caught in the crossfires of the increasingly oppressive postcolonial government of Daniel arap Moi, which was eager to launder money through dubious real estate developments on some of Kenya's prime real estate, for example, Uhuru Park in Nairobi. Her initial idea to plant trees, she wrote and spoke, was to solve an economic development problem for women who, as mothers and wives, were despairing with limited resources to feed their families. When she convinced a handful of women that one easy and affordable solution with long-term benefits to their economic problems was planting trees, neither she nor they foresaw that such a simple solution would take off and change all of their lives. ${ }^{32}$ This novel initiative earned her the 2004 Nobel Peace Prize for her work with the Green Belt Movement whose ideas and methodologies have spread around the world.

Her memoir Unbowed explores her journey from consumer of knowledge to technician of knowledge to intuitive inventor and innovator, demonstrating that historians of Africa, in whatever specialty, can make knowledge of the past relevant and meaningful to people's lives. Maathai moved from merely solving an economic development problem to seeking to renew indigenous people's relationship with the land and their now forgotten relationships with nature writ large. Maathai's work with women and communities in Kenya's rural spaces over time, affirmed what fellow Kenyan, Ali Mazrui, had intuited: geography is, indeed, the mother of history. She groped her way back to an engaged practice of ecological diversity she knew in her personal history. To my mind, Maathai practiced an engaged historical memory that participated in the planting of not only fast growing trees, but especially indigenous local species of trees, and in the process, participated in sifting history for usable memory to solve local problems without waiting on someone's charitable hand. ${ }^{33}$ Maathai's life history and work suggest that it is important that scholars not become mere practitioners of book learning, but engage as scholar-practitioners who research and write histories of the powerless. Research and writing about the agency of Africans that does not provide opportunities for their self-knowledge and actualisation protects the history and memory of the powerful. To say it another way: Western-attuned research on and in Africa, by Africans and Africanists, whose scholarship primarily serves academic careers more than the lives of the studied

32 Lisa Merton and Alan Dater, Taking Root: The Vision of Wangari Maathai (Malboro, VT: Malboro Productions, 2008).

33 On the reciprocal relationships the sycamore fig tree has with a variety of species, see the documentary film, Mark Deeble and Victoria Stone, The Queen of Trees, 2019, accessed December 18, 2020, https://www.youtube.com/watch?v=xy86ak2fQJM. 
is practicing history as memory for the powerful and the privileged. It is telling African stories accessible to a few who get the academic jargon, but not those whose lives and stories enrich the academic practitioner's life and career in the first place. I generalise, of course, and yes, giving back does not have to be Oprah-sized; the point is to break with that one-sided fact of academic research that largely benefits the academicians.

\section{Linda Tuhiwai Smith of New Zealand/Aotearoa}

In the process of re-reading Ngũgĩ wa Thiong'o's Decolonizing the Mind for my graduate work in Canada, I had my first encounter with the work of Linda Tuhiwai Smith of New Zealand/Aotearoa, a social theorist, historian of educational sociology, and indigenous researcher/activist. Her ground-breaking book Decolonizing Methodologies: Research and Indigenous Peoples followed in the critical tradition of Frantz Fanon, Edward Said, and especially Ngũgĩ wa Thiong'o whose aforementioned book, she said, inspired her own. ${ }^{34}$ Tuhiwai Smith put her finger on the pulse of Western academic production as a form of the continuing colonisation of the non-Western world, a system designed to study indigenous peoples rather than be tools for self- knowledge and actualisation. Reading Ngũgĩ's Decolonizing the Mind changed her perspective on Western education of formerly colonised peoples. Her work critiques the power of academic research that often affords even the most ordinary Westerners (and Western-educated indigenous peoples) the wherewithal to create narratives about the studied with often little accruing to those studied. These Western and western-oriented scholars bring their theories and methods, which, if not practiced with care, and critical engagement, vandalise people's sense of self even in the most well-meaning scenarios.

Tuhiwai Smith's major contention is that the conceptualisation, design, implementation, writing, and dissemination of research often empowers the researcher rather than the researched. This has had a knock-on effect on the use of unexamined theories, including runaway deconstruction that has become an end in itself. Her work reminded me, and reminds us all, that it behoves the historian, broadly defined, to practice with care because as far as the formerly colonised are concerned, historical research and the making of the archive often (though not always) are the memory and toolkit of the coloniser or the

34 Linda Tuhiwai Smith, Decolonizing Methodologies: Research and Indigenous Peoples (London: Zed Books, 1999). 
powerful. "The word 'research'," she writes at the beginning of her pathbreaking book, "is probably the dirtiest word among indigenous people." 35 By this expression, I understand her to mean that academia and the research process often empowers irresponsibility toward the studied, the researcher worries more about the Academic Review Board than the researched. Research also endows the researcher with unearned power over the studied; thus, research methodologies as practice, she reminds us, have to be critically examined as they are a poisoned inheritance from "explorers" and colonizers eager to imagine the savagery of $\mathrm{Na}$ tives in far flung places, than for mutually beneficial research. To that end, her wisdom is that those of us doing research among the disempowered, and especially the former colonised, have to be alert to complicit recruitment by an academy that continues the implicit debasement of indigenous peoples when research mostly benefits the outsiders more than the insiders. Tuhiwai Smith taught me that doing right by the former colonised or the powerless is not just about deconstructing colonial theories and methodologies to show one's book learning but centring the lives and stories of those who survived the traumas of colonialism and its long legacy evidenced by the continued plague of global racism. Like Maathai, Tuhiwai Smith returned herself to her intellectual home, and the community to itself so they could tell their own histories and stories, including their resilience in finding the salvageable indigenous ways of knowing whose shards remain in the once denigrated and diminished indigenous languages and systems that colonial powers far too often deemed mere savagery.

\section{Robin Wall Kimmerer of the Citizen Potawatomi Nation/USA.}

A member of the Citizen Potawatomi Nation, Robin Wall Kimmerer is a mother, scholar, and botanist. ${ }^{36}$ A bryologist and plant ecologist, Wall Kimmerer reopened a door I had almost sealed off and deemed unavailable to me in my pursuit of an historian's career that insisted on aloof objectivity. Through her first book, Gathering Moss, Wall Kimmerer breached the sound barrier between culture, nature, and history through her loving embrace of oral traditions in the dynamic

35 Ibid., 1.

36 Robin Wall Kimmerer, "Two Ways Of Knowing," interview by Leath Tonino, The Sun Magazine, April 2016, accessed 18 December 2020, https://www.thesunmagazine.org/issues/484/twoways-of-knowing. 
ways they occurred in their communities of origin. ${ }^{37}$ She enlivened the scientific method, whose practitioner had often struck a frozen pose behind the micro-ortelescope, by reimagining the use of scientific instruments to enhance, rather than diminish, indigenous ways of knowing. Wall Kimmerer brings to her work the painful and resilient worlds she inherited - the legacy of Native American dispossession, forced removals and alienation from the land through forced assimilation - histories of surviving and thriving despite it all. In her case, she is descendant from those who, when they were children, were removed from their families and communities to colonial boarding schools or "rehomed" with white families who would "clean" them of their imagined untamed cultures - the civilising mission.

In her book Braiding Sweetgrass: Indigenous Wisdom, Scientific Knowledge, and the Teachings of Plants, ${ }^{38}$ Wall Kimmerer writes as both poet and scientist, and most importantly for me, as a soul who knows that all of creation is one. Her research and writings about plants and the nature histories of the First Peoples of the Americas is done with great love, care, and rigor, balancing the subjective and objective in the telling of cultural and natural histories of human relations with plants, and plants' own relationships with one another. Her work showed me the importance of tenacity against the publish-or-perish academic treadmill that often forces people to produce works that are accessible to a few for the sake of promotion. Wall Kimmerer, like the other two women in this section, takes much of what academic science discarded as unscientific among Native American peoples and applies a rigorous scientific analysis of that discarded knowledge illumining not only the wisdom in their ways of knowing, but also the power and wisdom of the natural world that bends to entice humans into kinship, rather than relationships of domination and taming through taxonomies and profiteering. My reading of her two books drew me into a deeper curiosity about botany everywhere because she balances the wisdom traditions with "science [which] polishes our way of seeing and knowing" the world. ${ }^{39}$ Her research methods, to my mind, extend our senses so we can know what the ancients knew, those who lived in intimate relationships with their physical geographies and natural environments. For her, any research work and expertise

37 Robin Wall Kimmerer, Gathering Moss: A Natural and Cultural History of Mosses (Corvallis, OR: Oregon State University Press, 2003). I am not negating the work done by historians like Jan Vansina in the 1960s, but what I mean here is that Kimmerer is not into explaining how it works, but just doing it, especially in her second book.

38 Robin Wall Kimmerer, Braiding Sweetgrass: Indigenous Wisdom, Scientific Knowledge, and the Teachings of Plant (Minneapolis, MN: Milkweed Editions, 2014).

39 Ibid, 48. 
without relationships between plants and people reveals little and tells us more about the researchers whose (colonised) research methods narrow the range of possibilities of what can be known and how.

My reading of Robin Wall Kimmerer, is that the historian, broadly defined, is a memory keeper who is eager to reciprocate the gifts of history with a memory that liberates even history from itself. Her methodology is one that says the past contained in plant life, and in the natural world around us, is for us the living who reinvent traditions to pass them on as seed for the next generation. We, the living are the ones who are searching for meaning and depth, the ones who should challenge and resist unconscious consumption of anything in our world without asking what good can I do in return? How can I reciprocate the abundance before me? In my late mother's chiShona language, this idea is articulated as: "Katswanda kanoenda kwabva kamwe" ("When one receives a gift, reciprocity is only natural”). Wall Kimmerer's work as memory practitioner includes retrieving stolen tongues, including her own that she has had to learn in adulthood. By retrieving and salvaging what is possible, she brings forth not only what is possible, but also the importance of intimacy that holds reverence for the animacy of all living beings from moss to blue whales to elephants, ants, and butterflies. ${ }^{40}$ Her work is closest to what I learned from my own mother and grandmother, a practice of love, care, reciprocity, and kinship with all beings and my telling of their stories. That knowledge from my mother and her mother moves me to insist that the historian should be a practitioner of memory who returns the human to nature, so history is alive; not in fragments that build an academic historiography alone, but the wholeness of all who encounter the work. Our discipline and its historiography cannot be about piecing fragments together, its future may lie in the telling of the whole anew.

\section{Thanksgiving in Lieu of a Conclusion}

If I pinched a nerve too tight, know that I do not place myself above you, I am just as guilty and complicit in this erasure. My intent here is to pull back the veil on those discomforts we are often too polite to talk about in public in African Studies, and academia more generally. These are discomforts, which when named, often free us all from the fear that keep us wedded to the (guild) status quo rather

40 See, or listen to, her 2018 interview with Krista Tippett titled: "The Intelligence of All Kinds of Life”, accessed 18 December 2020, https://onbeing.org/programs/robin-wall-kimmerer-theintelligence-in-all-kinds-of-life-jul2018/. 
than to the truth that sets us all free. Thus, in lieu of a formal conclusion, I will circle back to Chipo, and that dead-but-alive tree stump. Sadly, Chipo died suddenly on $7^{\text {th }}$ November 2017, of a sterile brain infection that no one could explain. Nature had her way with a beloved canine. And yet, it is because of that beloved canine that I fully embraced the importance of the historian's engaged practice as deep scholarship. I often think that though the new shoots on that craggy dead stump in central Texas may have rejuvenated some life in its new shoots, considering where it was perched on a rock, it was also obvious to me that those shoots' future would not be long; it would be a struggle to bring back the same old vigour that the old tree once had. In other words, overt and subtle racist ways of relating to Africa, Africans, and people of African descent everywhere (including Switzerland) while still nourished by the dead tree stump of modern European imperialism, slavery, and colonialism, it is now a craggy old stump on the way out. As historians and scholars, we have an opportunity to not just dig up the poison of Hegel's racist pronouncements but do the real important work of prioritising the majority of Africans in our showing and telling of African Studies. That, indeed, maybe our more important task of bearing witness to African lives on the continent and in the diaspora; writing scholarship that rebukes white supremacy's innocence in everyday life whether here in Switzerland, Europe, or elsewhere. When care and reciprocity are central to one's practice of historiography, one elevates the practice of critical history into critical memory for the living.

\section{Bibliography}

Allen, Paula Gunn, ed. Spider Woman's Granddaughters: Traditional and Contemporary Writing by Native American Women. New York: Fawcett Books, 1989.

Baldwin, James. James Baldwin: Collected Essays. Collected by Toni Morrison. New York: The Library of America, 1998.

Biko, Steve. I Write What I Like: Selected Writings. Chicago: University of Chicago Press, 2002.

Chakrabarty, Dipesh. Provincializing Europe: Political Thought and Historical Difference. Princeton: Princeton University Press, 2007.

Charumbira, Ruramisai. Imagining a Nation: History and Memory in Making Zimbabwe. Charlottesville: University of Virginia Press, 2015.

Charumbira, Ruramisai. "Ancestor Worship: Just Who is Worshipping Whom?: Theoretical and Methodological Reflections on Power and Knowledge about Africa," M.A. thesis, University of Toronto, 2001, https://tspace.library.utoronto.ca/bitstream/1807/15836/1/ MQ63231.pdf.

Dalal, Farhad. “Jung: A Racist” British Journal of Psychotherapy, no. 4 (1988): 263-279.

Deloria, Vine, Jr. Custer Died for Your Sins: An Indian Manifesto. Norman: University of Oklahoma Press, 1988. 
Dunbar-Ortiz, Roxanne. An Indigenous Peoples' History of the United States. Boston: Beacon Press, 2014.

Fanon, Frantz. Black Skin, White Masks. New York: Grove Press Inc., 1967.

Fuglestad, Finn. "The Trevor-Roper Trap or the Imperialism of History: An Essay." History in Africa 19 (1992): 309-326.

Harjo, Joy. An American Sunrise: Poems. New York: W.W. Norton \& Company, 2019.

Hegel, Georg W.F. The Philosophy of History. Translated by J. Sibree. Kitchener: Batoche Books, 2001.

Kimmerer, Robin Wall. Gathering Moss: A Natural and Cultural History of Mosses. Corvallis: Oregon State University Press, 2003.

Kimmerer, Robin Wall. Braiding Sweetgrass: Indigenous Wisdom, Scientific Knowledge, and the Teachings of Plant. Minneapolis: Milkweed Editions, 2014.

Lafferty, Kevin D. and Thomas H. Suchanek. "Revisiting Paine's 1966 Sea Star Removal Experiment, the Most-Cited Empirical Article in the American Naturalist." American Naturalist 188, no. 4 (2016): 365-378.

Long Soldier, Layli. Whereas: Poems. Minneapolis: Graywolf Press, 2017.

Maathai, Wangari. Nobel Prize for Peace Lecture 2004. NobelPrize.org. Accessed 18 December 2020, https://www.nobelprize.org/prizes/peace/2004/maathai/26050-wangari-maathainobel-lecture-2004/.

Maathai, Wangari. Unbowed: A Memoir. New York: Alfred A. Knopf, 2006.

Maathai, Wangari. Replenishing the Earth: Spiritual Values for Healing Ourselves and the World. New York: Doubleday, 2010.

Mazrui, Ali. The Africans: A Triple Heritage. Boston: Little, Brown and Company, 1986.

Merton, Lisa, and Alan Dater. Taking Root: The Vision of Wangari Maathai. 2008.

Morrison, Toni. "A Humanist View.” In Portland State University, Public Speakers Collection, "Black Studies Center Public Dialogue. Pt. 2" (May 30, 1975). Special Collections: Oregon Public Speakers. 90.

Morrison, Toni. Playing in the Dark: Whiteness and the Literary Imagination. New York: Vintage Books, 1992.

Mugane, John. "Contemporary Conversations: Is English an African Language?” Journal of African Cultural Studies 30, no. 2 (2017): 121-123.

Orange, Tommy There There. New York: Vintage, 2019.

Purtschert, Patricia, and Harald Fischer-Tiné, eds. Colonial Switzerland: Rethinking Colonialism from the Margins. London: Palgrave Macmillan, 2015.

Robert W. Paine. "Food Web Complexity and Species Diversity," American Naturalist 100, no. 910 (1966): 65-75.

Ricoeur, Paul. Memory, History, Forgetting. Translated by Kathleen Blamey and David Pellauer. Chicago: University of Chicago Press, 2010.

Smith, Linda Tuhiwai. Decolonizing the Mind: Research and Indigenous Peoples. $2^{\text {nd }}$ edition. London: Zed Books, 2012.

Spyri, Johanna. Heidi. New York: Dell Publishing, 1990.

Thiong’o, Ngũgĩ wa. Decolonizing the Mind. Oxford: James Currey, 1986.

Thiong’o, Ngũgĩ wa. Something Torn and New: An African Renaissance. New York: BasicCivitas Books, 2009.

Thiong’o, Ngũgĩ wa. Re-membering Africa. Nairobi: East African Educational Publishers, 2009. 
